\title{
Assessment of Water Balance in the llauko Reservoir of the Ouémé at Savè Catchment (Benin, West Africa)
}

\author{
Amedée Chabi ${ }^{1, ~ *}$, Eric Adéchina Alamou ${ }^{2, ~ *, ~ E l i e ́ z e r ~ I b o u k o u n ~ B i a o ~}{ }^{3, ~ *, ~ E z e ́ c h i e l ~ O b a d a ~}{ }^{2, ~ *, ~}$ \\ Josué Zandagba, \\ ${ }^{1}$ International Chair in Mathematical Physics and Applications (ICMPA), Cotonou, Benin \\ ${ }^{2}$ Laboratoire d'Hydrologie Appliquée (LHA), Abomey-Calavi, Benin, Institut National de l'Eau (INE), Abomey-Calavi, Benin \\ ${ }^{3}$ West African Science Service Center on Climate Change and Adapted Land Use (WASCAL), Abomey-Calavi, Benin, Institut National de \\ l'Eau (INE), Abomey-Calavi, Benin
}

\section{Email address:}

amedees2005@yahoo.fr (A. Chabi), ericalamou@yahoo.fr (E. A. Alamou), biaoeliezer@yahoo.fr (E. I. Biao),

e.obada83@yahoo.fr (E. Obada),Zjosua@yahoo.fr (J. Zandagba)

${ }^{*}$ Corresponding author

\section{To cite this article:}

Amedée Chabi, Eric Adéchina Alamou, Eliézer Iboukoun Biao, Ezéchiel Obada, Josué Zandagba. Assessment of Water Balance in the Ilauko Reservoir of the Ouémé at Savè Catchment (Benin, West Africa). Hydrology. Vol. 7, No. 1, 2019, pp. 15-23.

doi: $10.11648 /$ j.hyd.20190701.13

Received: March 12, 2019; Accepted: April 28, 2019; Published: May 23, 2019

\begin{abstract}
This study deals with the management of the Ilauko reservoir of the SUCOBÉ SA Company, well known as the "Society Sucrière of Savè" (SSS), which is located in the Oueme at Save catchment. The objective of this paper is to assess the water balance in this reservoir. A better knowledge of this water balance will allow reducing, in the short, medium and long term, water shortages due to climate change. It will also allow facing the water needs of the populations. The water balance was used as an approach to estimate the water input to the watershed. Its application derives from the conservation principle of water volumes. The results show that on Ilauko reservoir, the inflows are greater than the outflows. Thus, the annual variation of the volumes in the reservoir that are obtained in 2012 and 2013 are positive and are respectively $2,179,215 \mathrm{~m}^{3}$ and 598,452 $\mathrm{m}^{3}$. By this fact, there are less of anthropic activities that are exerted on the reservoir during these periods. Furthermore, it was noted that, on the Ilauko dam, $68 \%$ of the water volumes are evaporated, $0.5 \%$ are infiltrated and $32 \%$ are withdrawn to face the irrigation needs and drinking water supply of Savè town and its surroundings.
\end{abstract}

Keywords: Reservoir, Assessment, Catchment, Climate Change, Water Balance

\section{Introduction}

Nowadays, the crucial role of dams in water management reveals an increasing importance. The dams provide the means necessary to preserve sustainable water resources, aquatic life and protection of erosion. The Ilauko reservoir, which has the capacity of storing 24 million $\mathrm{m}^{3}$ of water, has recently been the focus of so many researches. The developments of the economy sectors of the SUCOBE SA Company, as well as the population well-being are dependent on water resources. Therefore, a well-designed conservation measures and rational management of water resources is required. Quantitative and qualitative access of water resources by populations varies in time and space. The reservoir, which is studied in this paper, was built with the aim to irrigate a unit sugar cane production by gravity for the benefit of the aforementioned company. However, the surrounding population encounters some difficulties, especially in the dry season, for water supply. According to study of [1], the town of Savè was supplied by (04) low-flow boreholes, which varied from 3 to $12 \mathrm{~m}^{3} / \mathrm{h}$ in the rainy season and fall between 1 to $5 \mathrm{~m}^{3} / \mathrm{h}$ during the dry season. Water scarcity is due to the hydro geological characteristics of the crystalline basement. Groundwater resources are limited and difficult to access due to rainfall irregularities caused by climate change. Similarly, the works of [2], revealed a drainage deficit of about $40 \%$ in the Ouémé at Bétérou and Savè catchments. According to the same authors, this decline in flow corresponds to a decrease in rainfall 
ranging from 15 to $20 \%$. The Ouémé catchment presents a major advantage, since it drains $65 \%$ of surface water and $60 \%$ of groundwater in the country [3]. Moreover, in the Ouémé at Savè sub-catchment, it is noticed that only $13 \%$ of water resources are acceptable quality, while in quantitative terms, the catchment produces nearly 750 times. To this end, a memorandum of understanding was signed in 2007 between SUCOBE SA (manager of the sugar company) and SONEB (company in charge of providing drinking water). This protocol concerns the use of water from the Ilauko reservoir for the supply of drinking water to the town of Savè, at a rate of $800 \mathrm{~m}^{3}$ / day, i.e $292,000 \mathrm{~m}^{3}$ / year, which is about $2 \%$ of the useful volume, representing water consumption [1, 4].

From this perspective, agricultural water demands in sugar cane crops, by population and other uses continue to grow. To this end, a study of the filling balance of the Ilauko reservoir showed that the loss by evaporation was 5 million $\mathrm{m}^{3}$, i.e. $31 \%$ of its useful volume, the balance without the drinking water supply has a deficit of 1 million $\mathrm{m}^{3}$, which is about $6 \%$ of the working volume; the balance with drinking water supply has a deficit of 1.1 million $\mathrm{m}^{3}$, representing $7 \%$ of the useful volume. However, the dam is currently exploited by three main actors: the Savè Sugar Society (SSS) for the irrigation of sugar cane on an area of 5500 ha, the drinking water supply by SONEB and the Livestock. For a good planning and sustainable management of water resources, establishment of a reliable hydrological balance of hydraulic systems becomes a major scientific issue [5-7]. Several studies have been carried out in the field of hydrological modeling, either on a catchment or on a reservoir. Hydrological balance model based on the application of the water balance equation resulting from the principle of conservation of water volumes has been choosen by [8-11], and [12].

Therefore, this paper proposes to evaluate water resources in Ilauko reservoir for an efficient use and equitable access. components in terms of the reservoir hydrological balance by taking into account the uncertainties.

\section{Data and Methods}

\subsection{Study Area}

The Ilauko reservoir (Figure 1) is located in the area of Savè (Benin, West Africa). Situated in a basement area, the Ilauko dam is fed by the Ouémé River, which has a length of about $500 \mathrm{~m}$, and has an outlet at the bridge of Savè at Atchakpa Oueme at Savè catchment extends between $8{ }^{\circ} 00^{\prime} 0$ " and $8^{\circ} 77^{\prime} 30^{\prime \prime}$ North latitude and $2^{\circ} 19$ '30' 'and $2^{\circ} 25^{\prime} 0^{\prime}$ 'East longitude. It was built between the years 1978-1980 by a French company, named GTE (Great Works- of the East) under the control of HHS (Han Howard Humphleys and Sons). In addition, the dam has the characteristics summarized in Tables 1 and 2.

Table 1. Morphological characteristic of the Ilauko dam.

\begin{tabular}{ll}
\hline Designations & Quantities \\
\hline Nature & Dam \\
\hline Year of construction & 1980 \\
Main river & Ilauko \\
Area of the dam (ha) & 445 \\
Watershed area $\left(\mathrm{Km}^{2}\right)$ & 20 \\
Storage volume dam $\left(\mathrm{m}^{3}\right)$ & 24 millions \\
Useful volume $\left(\mathrm{m}^{3}\right)$ & 16 millions \\
Dead Capacity of the Hold $\left(\mathrm{m}^{3}\right)$ & 8 millions \\
Volume stored dry season $\left(\mathrm{m}^{3}\right)$ & 500 mille \\
Width of the crest of the dam at crossing (m) & 8 \\
Length of the dike $(\mathrm{Km})$ & 1.210 \\
Useful depth (limnometric scale level) (m) & 22 \\
Coast/Level Natural soil $(\mathrm{m})$ & 104 \\
Height at the dam (crest of the dam) $(\mathrm{m})$ & 126 \\
Base- dam (m) & 100 \\
Maximum filling (m) & 124 \\
\hline
\end{tabular}
To achieve this objective, this study quantifies the

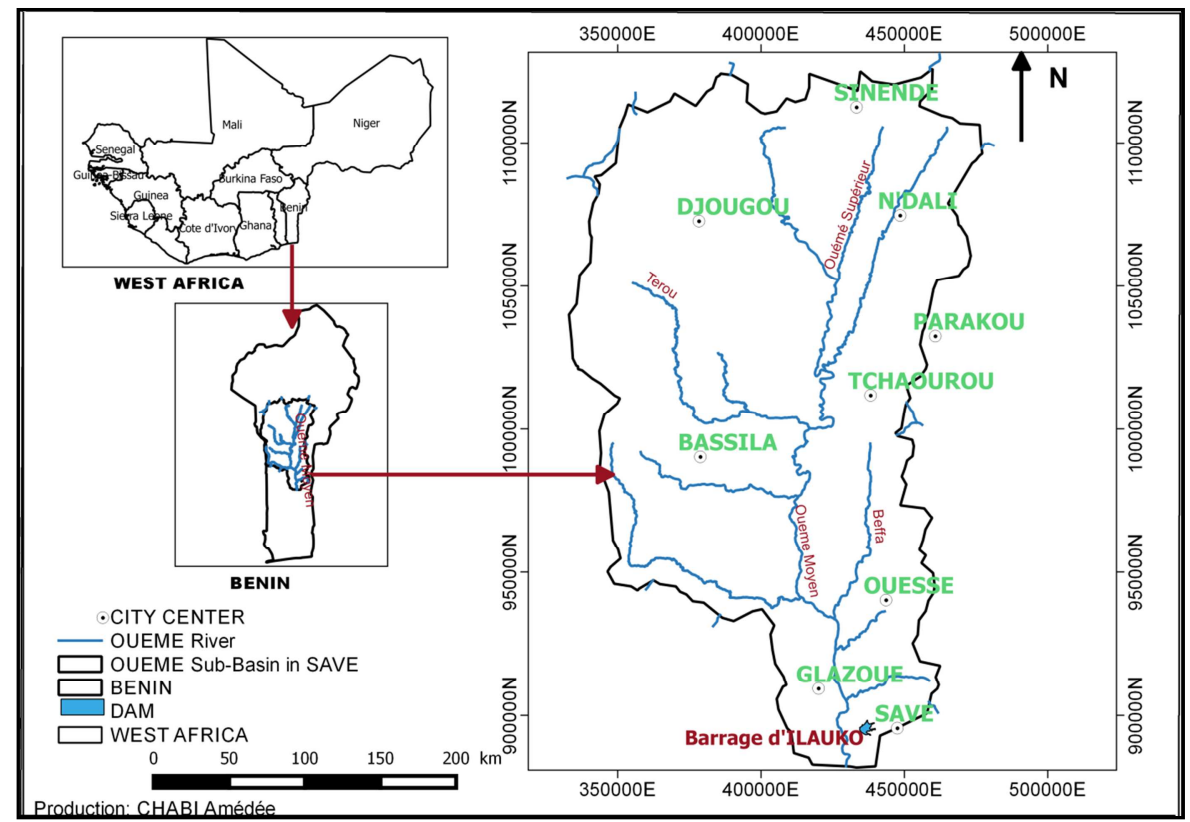

Figure 1. Location of the Ilauko reservoir in the Ouémé at Savè catchment. (Source; data from [13]). 
Table 2. Characteristic flow rates of the pumps at the Ilauko site.

\begin{tabular}{|c|c|c|c|c|c|}
\hline \multirow{2}{*}{ ZONES } & \multicolumn{3}{|c|}{ STATION N 1} & \multirow{2}{*}{$\begin{array}{l}\text { STATION No2 } \\
\text { D-E }\end{array}$} & \multirow{2}{*}{ STATION N’3 } \\
\hline & $\mathbf{A}$ & B & $\mathbf{C}$ & & \\
\hline \multirow{3}{*}{ PUMPS/FLOWS (L/S) } & $1 \mathrm{P} / 160$ & $1 \mathrm{P} / 160$ & $1 \mathrm{P} / 170$ & $1 \mathrm{P} / 150$ & $1 \mathrm{P} / 0,768$ \\
\hline & $2 \mathrm{P} / 310$ & $2 \mathrm{P} / 320$ & $2 \mathrm{P} / 330$ & $4 \mathrm{P} / 600$ & $02 \mathrm{P} / 1,536$ \\
\hline & $4 \mathrm{P} / 625$ & $3 \mathrm{P} / 480$ & $3 \mathrm{P} / 500$ & $5 \mathrm{P} / 760$ et $6 \mathrm{P} / 915$ & $05 \mathrm{P} / 3,84$ \\
\hline PUMPS/TOTAL & 4 & 3 & 3 & 6 & 5 \\
\hline
\end{tabular}

The data used in this study were obtained from the meteorological stations of the dam, as well as from the SONEB. These include rainfall, temperature, evaporation, volume for reservoir capacity, coastal data (water level), area of the Ilauko reservoir and water pumped at daily time step by the SONEB from the dam towards the treatment center station of Gobé, and covers the period from 2009 to 2014 .

\subsection{Methods Used}

To better quantify the hydrological variables (precipitation, evaporation, etc.), the hydrological balance is used to estimate the supplies and withdrawals in the Ilauko reservoir.

\subsubsection{Reservoir Water Balance}

The water balance in the Ilauko reservoir is estimated on the basis of the principle of conservation of water volumes. Over a given period of time, the general equation of the hydrological balance of a reservoir can be written:

$$
\Delta V=V_{p}^{t}+V_{r s}^{t}+V_{e c s}^{t}-V_{e}^{t}-V_{i}^{t}-V_{d}^{t}-V_{u}^{t}
$$

$\Delta V:$ Variation of the water stock in the tank.

$V_{p} ; V_{r s} ; V_{e c s}$ : Input volumes representing respectively the inputs due to precipitation falling directly into the reservoir, artificial pumping intake from tributaries, subsurface inputs and snowmelt inflows in $\left(\mathrm{m}^{3}\right)$;

$V_{e}, V_{i}, V_{d}$ et $V_{u}$ : Outflow volumes of reservoir representing respectively the volume of water evaporated, the infiltration losses (at the level of the dam and in the bottom of the reservoir), the volume of water leaving the reservoir by spill and the volume of water taken for various use $\left(\mathrm{m}^{3}\right)$;

In this study, groundwater inputs (Vecs) are assumed to be zero due to the absence of snow in the area and the hydrogeological characteristics of the crystalline basement of the area of study, which does not favor the formation of underground flows. Moreover, the dam has never experienced an over flow since its creation.

\subsubsection{Assessment of Inputs Due to Precipitation Failing Into the Reservoir}

The contribution of rainfall falling directly to a reservoir is equal to the water precipitated, in the year, by the surface of the water body [14]. Thus, we have:

$$
V_{p}=\text { Area } \times \text { precipitated blade over one year }
$$

The volume precipitated over the water during a time interval $\Delta \mathrm{t}$ is defined as follows $[15,16]$ and $[12]$.

$$
V_{p}^{t}=A_{r}^{t} \times P^{t} / 1000
$$

$\mathrm{V}_{\mathrm{p}}^{\mathrm{t}}$ : Precipitation inputs at the site $\left(\mathrm{m}^{3}\right), \mathrm{A}_{\mathrm{r} \text { : Water }}^{\mathrm{t}}$ reservoir area (ha), and $\mathrm{P}^{\mathrm{t}:}$ Height of rain $(\mathrm{mm})$. With $1 \mathrm{~mm}$ $=10^{3} \cdot \mathrm{m}^{3} \cdot$ ha.

\subsubsection{Estimation of Supplies by Runoff}

In addition, pumping water from the river to the reservoir is done to mitigate the drought (July, August and September), in order to face the multiple use needs.

In addition, the Station No. 3 has five (05) pumpshowever four (4) of them are functional. On average one or two (02) pumps are frequently used, due to the high cost of fuels, with a flow rate equal to $0.768 \mathrm{~m}^{3} / \mathrm{s}$ and $1,536 \mathrm{~m}^{3} / \mathrm{s}$. Finally, the various data collected from the field will allow a synthesis in terms of the combination of inputs from the upstream catchment area and the artificial pumping of water downstream to supply the reservoir. For this purpose, the inputs on the slopes are assumed here to be equal to zero. Thus, equation (4) can be written as follows:

$$
V_{r s}^{t}=\Delta V-V_{p}^{t}+V_{e}^{t}+V_{i}^{t}+V_{d}^{t}
$$

\section{$\mathrm{V}_{\mathrm{rs}}^{\mathrm{t}}$ Watershed runoff $\left(\mathrm{m}^{3}\right)$}

\subsubsection{Evaluation of Evaporation Losses}

Several methods have been proposed to estimate the evaporation of surface water and for reservoirs by $[10,17$, 18]. However, the choice of a method depends on the availability of the data. In this study, the volume evaporated during a time interval $\Delta \mathrm{t}$ is estimated as the product of the evaporation rate by the mean surface of the body of water during the time interval considered (equation 5). Evaporation at the Ilauko reservoir is estimated from a standard class A evaporation tank, set up and located almost at $100 \mathrm{~m}$ from the dam on the bare soil. Several authors have estimated that the correct and mostly used correction coefficient (Equation 6) for the Class A tank varies between 0.6 and 0.8 depending on the extent or depth of the body of water. For this study, the average ranging between these two variations, i.e. 0.7 is attributed to the correction coefficient of the tank, to estimate the evaporation on the Ilauko reservoir. The use of this value is justified by the results obtained on the site by [4] and [12].

$$
\begin{gathered}
V_{e}^{t}=A_{r}^{t} \times E_{r e t}^{t} / 1000 \\
E_{r e t}^{t}=K_{b a c} \times E_{b a c}^{t}
\end{gathered}
$$


$\mathrm{K}_{\mathrm{bac}}$ is the coefficient of transposition (correction) of evaporation tank; Evaporation of the reservoir; and is the area of the reservoir in ha.

\subsubsection{Estimation of Infiltration Losses}

Underground inputs are not considered in this study because of the nature of the soil in the study area. In general, for the establishment of the water balance of the tanks, infiltration is not often seen because it is a difficult component to express $[19,20]$. However, it is often estimated during low-water periods, with no reservoir inputs and low or negligible sampling $[21,22,23,24]$. Thus, equation 1 is reduced to equation 7 :

$$
V_{\text {inf }}^{t}=V_{s}{ }^{t}-V_{s}{ }^{t+1}-V_{\text {evap }}^{t}
$$

with $\mathrm{V}_{\text {inf: }}$ Volume representing infiltration losses at the upend bottom of the dam;

$\mathrm{V}_{\mathrm{s}}^{\mathrm{t}}$ : Volume of inputs at time $\mathrm{t} ; \mathrm{V}_{\mathrm{s}}^{\mathrm{t}+1}$ : Volume of outflows

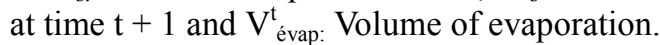

When the variation volume of the reservoir $(\Delta \mathrm{V})$ is changed by variation of height $(\Delta \mathrm{h})$, that is assumed to be small so that the surface area of the reservoir can be neglect, the infiltration rate can be estimated as follows [12]:

$$
I_{f}^{t}=-\Delta h-E_{r e t}^{t}
$$

Where $\mathrm{I}_{\mathrm{f}}^{\mathrm{t}}$ represents the infiltration rate $\left(\mathrm{mm} \cdot \Delta \mathrm{t}^{-1}\right) ; \Delta \mathrm{h}$ the variation of the coast per unit time $\left(\mathrm{mm} \cdot \Delta \mathrm{t}^{-1}\right)$ and $\mathrm{E}_{\mathrm{r}}^{\mathrm{t}}$ the evaporation rate in $\left(\mathrm{mm} . \Delta \mathrm{t}^{-1}\right)$.

\subsubsection{Sampling at the Reservoir for Various Uses}

Water sampling at Ilauko is done mainly in three different sectors: agriculture (irrigation), livestock and drinking water supply of the population. The various data collected in Agriculture and drinking water supply during the crop year 2012-2013, were used to determine the amount of water taken by each sector of activity. In the case of livestock, there is no data that clearly shows the amount of water consumed by livestock. Nevertheless, it was also estimated in the same way as the other sectors of activity by the residual storage equation during the dry period.

(i) Estimation of Water in Sugar Cane Cultivation and Domestic Use

Estimates of water requirements in these different sectors are based on reports prepared by the Irrigation Department (SUCOBE SA and SONEB) for the drinking water supply at Savè area. For this purpose the data obtained from these reports were calculated and evaluated at monthly scale and by compartment to estimate the water volumes in each of these sectors of activity.

(ii) Estimation of Livestock Volumes

The access of livestock is limited between 200 to 300 cattles per day. The animals that use the reservoir are cattle, goats and sheep. Based on the conversion of livestock into a Tropical Livestock Unit (TLU), water consumption foreach type of livestock is estimated on the Ilauko dam. The ratio of the metabolic weights is fixed at 0.7 TLU for one (01) cattle;
1.15TLU for one (01) sheepand 0.2 TLU for one (01) goat. The considered daily water requirements are $40 \mathrm{l} / \mathrm{day} / \mathrm{TLU}$, i.e. $0.040 \mathrm{~m}^{3} /$ day / TLU [25].

\subsubsection{Uncertainties Analysis}

The uncertainties in the terms of water balance may arise from measurement errors, approximations in the calculation method, errors in some parameters used to calculate certain terms and the transposition of regional data into a specific site [26, 27]. The measures of the terms of water balance require a variety of approaches and each one is a source of uncertainty [12]. The uncertainty associated to precipitation measurements due to the errors of the rain gauge installation, varies from 5 to $10 \%$, and those related to discharge flows are less than 5\% [26]. These errors, which are difficult to correct, may come from the observer's reading [28, 29]. Moreover, the uncertainties in evaporation estimation are mainly due to the transposition of the data [30, 31]. A precision of 10 to $15 \%$ has been proposed on the evaporation data of free water bodies, taking into account the transposition coefficient and the climatic regime [28]. The energy balance methods are considered as the most reliable with an accuracy of around 10\% [32].

In the present study, the errors related to the measures of annual rainfall were set at $10 \%$, those of the annual evaporation to $15 \%$. The uncertainties associated with the remains of the unknowns (infiltration, intake by runoff and sampling for various uses) are estimated as follows [33, 34].

$$
\delta(X)=\left[\sum_{i} \delta^{2}\left(Y_{i}\right)\right]^{\frac{1}{2}}
$$

where $\delta(\mathrm{x})$ is the absolute error associated with the residual term $\mathrm{X}$; (Yi) and $\varepsilon_{y_{i}}$ respectively denote the absolute error and the relative error associated with each of Yi terms belonging to the reduced balance equation that enable the estimation ofthe term $\mathrm{X}$. The expression of the absolute error taking into account the variation of the level of water in the reservoir is as follows:

$$
\delta H_{S}=\delta W L
$$

$\delta W L$ represents the absolute error according to the daily variation of the water level $(\mathrm{m})$.

\section{Results and Discussion}

\subsection{Analysis of Rainfall and Evaporations}

\subsubsection{Analysis of Rainfall}

Analysis of observed rainfall at the Ilauko site during the 2012 (April-12 and March-13), 2013 (April-13-March-14) and 2014 (April-14- December-14) rainy seasons, reveals that the totals of their accumulation are respectively $808.5 ; 616.8$ and $974.9 \mathrm{~mm}$. These accumulations are consistent with the accumulation observed at the scale of the Ouémé basin at Savè over the period 2000-2009, which is around $803.5 \mathrm{~mm}$ [35]. 
This comparison shows that the rainy seasons of the years 2012 and 2014 were in surplus, whereas the rainy season of the year 2013 has a deficit of about $22 \%$. The annual cumulative volumes of precipitated waters correspond respectively to $3597825 \mathrm{~m}^{3}, 2744760 \mathrm{~m}^{3}$ and $4338527.5 \mathrm{~m}^{3}$. Among other things, the total number of rainy days for these periods was 61 , 51 and 66 with the maximum daily rainfall observed in April $2012(53.3 \mathrm{~mm})$ and in July $2014(53.1 \mathrm{~mm})$, while the minimum values appeared in August, 2013 (49.3 mm) and $2014(49.1 \mathrm{~mm})$. The monthly distribution of precipitation reveals that, the rainy season extends from April to October. The wettest month is May in 2012 (Figure 2). For the year 2013, the maximum monthly rains are recorded in March and April (exceptional rain), while this maximum appeared in September for the year 2014. The dry season covers the period from November to March.

The rainfall deficits of about $22 \%$ which is obtained on the site during the 2012 and 2013 seasons can be explained by an interannual rainfall irregularity in both their abundance and their distribution, due to climate variability. Nevertheless, the rain surpluses obtained in September 2014, were due to an intermittent precipitation on the site.

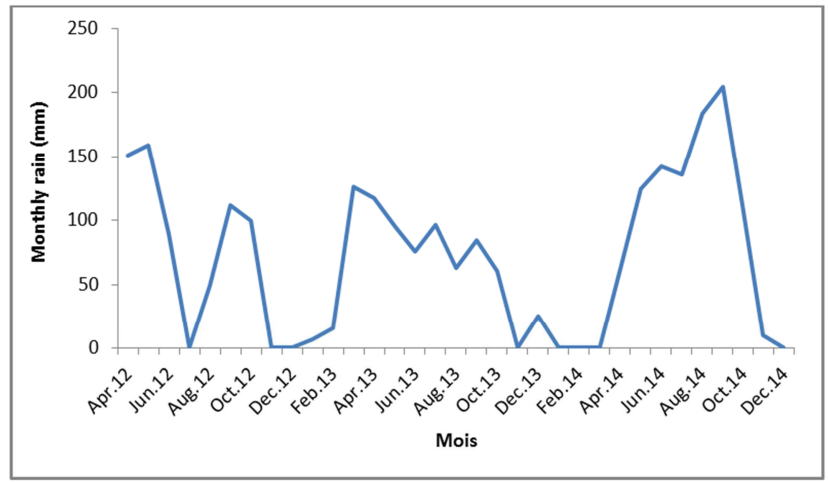

Figure 2. Monthly change in rainfall over the period April-12/March-13, April-13/March-14 and April-14/Dec-14.

\subsubsection{Analysis of Losses Due to Evaporation}

Analysis of the observed evaporation in the Ilauko dam (Figure 3) reveals that the accumulation of the evaporated water are respectively $1574.67 \mathrm{~mm}, 1775.88 \mathrm{~mm}$ and $1148 \mathrm{~mm}$ during the 2012 rainy seasons (April-12/March-13), 2013 (April-13/March14) and 2014 (April-14/December-14). Taking into account the transposition coefficient of the reservoir, for the full seasons of 2012 and 2013, the evaporation at the site is evaluated at 1102.27 $\mathrm{mm}$ and $1243.12 \mathrm{~mm}$. The volumes corresponding to this effect are respectively evaluated at $4,905,102 \mathrm{~m}^{3}$ and 5,531,866 $\mathrm{m}^{3}$, with a percentage of the order of $30.65 \%$ and $34.57 \%$ of the working reservoir volume. The monthly distribution of evaporation shows a weak variation rate between May and October of the full season of 2012-2013 and from August to November of the incomplete season 2014, with the lowest monthly rates in August. Nevertheless, we notice high values from November to May 2012-2013 and 2013-2014, with peaks in February 2013 and 2014. It is evident from this analysis that evaporation is more intense in 2014 than the other two years. This evaporation has increased by $4 \%$ between the periods 2012 and 2014. However, the volumes of water evaporated during the full seasons of 2012 and 2013 are in line with those obtained by [1]. Indeed, these authors found that the evaporation losses at the dam in 2012 is around 5 millionm $^{3}$, representing $31 \%$ of the working volume. The evaporation losses would have been evaluated at $3.03 \mathrm{~mm} /$ day, $4,921,477.5 \mathrm{~m}^{3} /$ year [4].

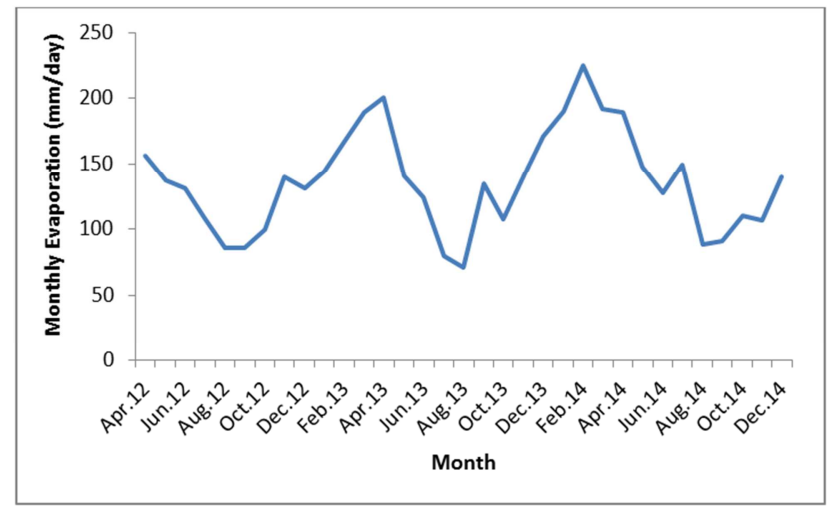

Figure 3. Evolution of monthly evaporation at the level of the evaporation tank of class A at the site of Ilauko according to the periods 2012 to 2014.

Intensification of evaporation on the Ilauko reservoir during all season's can be attributed to the effects of climate change on water resources. This evaporation could make the reservoir less efficient compared to large dams. This is the reason why evaporation is considered as a major factor in the reduction of reservoir water stocks [15].

\subsection{Water Supply by Runoff on the Ilauko Reservoir}

Analysis of survey results during the reporting period reveals that the majority of water supplies obtained in terms of runoff on the Ilauko reservoir stem from Ouémé (Savè) through the pumping station No. 3, installed on its watercourse. Estimation of water volumes, based on the hypothesis of the use of one or two pumps, can be summarized in the table 3 .

Table 3. Volume of water pumped from station No. 3 to the dam.

\begin{tabular}{ll}
\hline PUMPS & VOLUMES $\left(\mathbf{m}^{3}\right)$ PERIODS \\
\hline $01 \mathrm{P}$ & $1,799,000$ November-December $(2012)$ \\
$02 \mathrm{P}$ & $3,102,000$ September-December $(2013)$ \\
$02 \mathrm{P}$ & $10,698,800$ June - December $(2014)$ \\
TOTAL & $15,599,800$ \\
\hline
\end{tabular}

Table 3 shows that the volume of water in the dam increases from year to year, and is higher in 2014 than those of the two other years 2012 and 2013. This is due to a high rate of demand by users.

\subsection{Variation of the Water Level in the Reservoir of Ilauko}

The Ilauko reservoir is subject to a change in the way it is filling during the low-water period between 2012 (April12/March-13), 2013 (April-13/March-14) and 2014 (April14/December-14) (Figure 4). The minimum ratings in the Ilauko reservoir were observed at the end of December 2012; 
January-February 2013 and November-December 2013 and 2014. They correspond to a recession phase, with the following levels: $122.15 \mathrm{~m}$ on $27-12-2012 ; 120.25 \mathrm{~m}$ on 30 $12-2013$ and $120.28 \mathrm{~m}$ on $26-12-2014$. The volumes of water in the reservoir corresponding to these dimensions are of the order of $13,090,000 \mathrm{~m}^{3} ; 13,540,000 \mathrm{~m}^{3}$ and 11,800,000 $\mathrm{m}^{3}$. The maximum annual water level values in the reservoir are obtained between April-November 2012, June-September 2013 and January and September 2014 (flood phase). These maximum levels are: $124.270 \mathrm{~m}$ on $15-11-2012 ; 123.97 \mathrm{~m}$ on 27-09-2013 and $123.1 \mathrm{~m}$ on 28-09-2014. The level reached on 15-11-2012 corresponds to a slight overflow of $0.42 \mathrm{~m}$ compared to the maximum level of filling of the dam which is equal to $124 \mathrm{~m}$. The volumes corresponding to these maximum annual levels are respectively: 24,850,000 $\mathrm{m}^{3}$; $21,660,000 \mathrm{~m}^{3}$ and $20,500,000 \mathrm{~m}^{3}$. The minimums observed at the level of the Ilauko reservoir during the follow-up period are linked to the various samplings taken by the actors involved in the use of water on the site for multiple uses during periods of drought (agriculture, livestock). These minimums could also be linked to the climate variability and change which impacts the dynamics of water resources (evaporation and infiltration...). The increase in water levels in the Ilauko reservoir during the period of November 2012 and from October 2013 to 2014 could be explained by the abundance of an intermittent flood in the basin due to its poor distribution in time and space. This period corresponds to the period of long rainfall seasons in the region. It could then be due to the pumping effect of water from the Oueme River to supply the reservoir. Finally, it can be due by the uncontrolled flows of water observed at the slopes or banks.

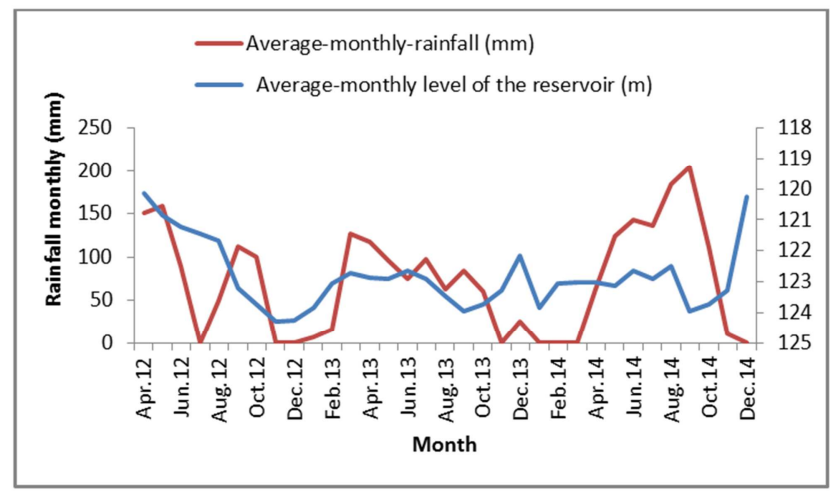

Figure 4. Variation in the state of filling of the Ilauko reservoir during the dry season and rainy season (2012-2013)-(2013-2014).

\subsection{Losses by Infiltrations}

The infiltration rate assessed on the Ilauko reservoir during the dry season of November 2012-March 2013 and November 2013-March 2014 ranges from $6.72 \mathrm{~mm} /$ day to $8.02 \mathrm{~mm} /$ day. Assuming that this rate remains unchanged for all the other months of the study period, it follows that the volumes of water infiltrated over the periods April 2012March 2013 and April 2013-March 2014 are respectively estimated at $35,689 \mathrm{~m}^{3}$ and $30,000 \mathrm{~m}^{3}$. These results are consistent with those found by [4]. The author shows at study through that the infiltration at the Ilauko site is $36,500 \mathrm{~m}^{3}$.

\subsection{Volumes Taken from the Dam for Various Uses}

\subsubsection{Water Withdrawn for Agricultural and Industrial Purposes}

Irrigation of sugar cane on the Ilauko site occurs frequently during the drought period. It is done according to the distribution zones on the site. Water drainage is done through a piping system fed with the pumps of stations No 1 and No 2, installed not far from the dam.

Table 4 shows that, over an area of 5500 ha of which the site has 5314.4 ha and 5195 ha for sugar cane planting, are actually exploited by designated areas, zone (ABC) and zone (DE) in March and December 2012; January and February 2013. The area sown in 2012 increases by $10 \%$ in relation to the total area. The water volumes used in the production of sugarcane are estimated respectively to1, 695,296 $\mathrm{m}^{3}$ and $1,779,732 \mathrm{~m}^{3}$ and correspond to $11 \%$ of the working volume of the reservoir. In addition, the water used for the functioning of the factory during the cropping season is estimated to $5000 \mathrm{~m}^{3} /$ day. Indeed, for four (04) months per year, i.e. 120 days corresponding to the duration of a campaign in one year, the volume of water used is estimated at $600.000 \mathrm{~m}^{3}$. It stems from this analysis that there has been more land used for agriculture than what was estimated, with a slight increase in the production rate estimated at $10 \%$ of the total percentage provided for this purpose. As a result, this increase is due to high demand for agricultural products (sugar cane) on the domestic and international market. Basically, the amount of water used in the factory for sugar cane production is negligible compared to that used in the crop, i.e. $4 \%$ of the working volume of the Ilauko reservoir.

Table 4. Water requirements for sugar cane production: Ilauko site.

\begin{tabular}{|c|c|c|c|c|c|c|}
\hline \multicolumn{7}{|c|}{ MONTHLY REPORT OF THE AGRICULTURAL CAMPAIGN FROM: 2012 - 2013} \\
\hline \multirow{2}{*}{ ZONES DESIGNATIONS } & \multicolumn{2}{|c|}{ STATION N¹ } & \multicolumn{2}{|c|}{ STATION N² } & \multirow{2}{*}{ TOTAL } & \multirow{2}{*}{ YEARS } \\
\hline & $\mathbf{A}$ & B & $\mathbf{C}$ & D-E & & \\
\hline Irrigated area (ha) & 717.02 & 717.12 & 504.8 & 748.88 & 2687.82 & \multirow{2}{*}{ March-2012 } \\
\hline Volume used $\left(\mathrm{m}^{3}\right)$ & 188352 & 192672 & 170208 & 265356 & 816588 & \\
\hline Irrigated area (ha) & 451.44 & 552.96 & 583.2 & 1038.96 & 2626.56 & \multirow{2}{*}{ December-2012 } \\
\hline Volume used $\left(\mathrm{m}^{3}\right)$ & 158004 & 194204 & 162864 & 363636 & 878708 & \\
\hline Irrigated area (ha) & 371.52 & 598.32 & 693.36 & 956.88 & 2620.08 & January-2013 \\
\hline Irrigated area (ha) & 557.28 & 617.76 & 587.52 & 812.16 & 2574.72 & \multirow{2}{*}{ February-2013 } \\
\hline Volume used $\left(\mathrm{m}^{3}\right)$ & 195048 & 216216 & 205632 & 281664 & 898560 & \\
\hline
\end{tabular}




\subsubsection{Volumes Withdrawn for the Supply of Drinking Water}

Figure 5 shows the monthly evolution of the volumes of water collected, produced and sold by SONEB, and the number of subscribers in Save. Analysis of these curves reveals that the months of April 2012; February, March and December 2013-2014 and May 2014, are the months of high water demand.

There is also an increase in the volumes withdrawn, produced and sold from 2012 to 2014. This can be explained by the continuous increase in the number of subscribers of the SONEB. Also, there is a correlation between the volumes of raw water withdrawn and the volumes of product and sold from 2012 to 2014. The volumes of water withdrawn and produced are each time approximately equal, thus the volumes sold are always lower than the volumes taken. However, it should be noted that the accumulation volumes of raw water taken from the site during the full seasons of 2012-2013 and 2013-2014 are successively evaluated at $152,242 \mathrm{~m}^{3}$ and $174,518 \mathrm{~m}^{3}$. During the incomplete season of 2014, the accumulation volume of water is estimated at $142,855 \mathrm{~m}^{3}$. Overall, the population's raw water requirements increases periodically over time, with high demand estimated at $202,973 \mathrm{~m}^{3}$ in 2014, which represent $1.3 \%$ of the reservoir's effective volume. These results are in line with those obtained by $[1,4]$. Indeed, these authors estimated that the water requirements for the drinking water supply from 2009 to 2012 could reach $800 \mathrm{~m}^{3} /$ day, i.e. $292,000 \mathrm{~m}^{3} /$ year. This volume is equivalent to $2 \%$ of the useful volume of the tank. Similarly, for a complementary need of water for the town of Savè and its surroundings, the water requirement is evaluated at $3481 \mathrm{~m}^{3} /$ day, compared to $800 \mathrm{~m}^{3}$ /day which is the current demand [4].

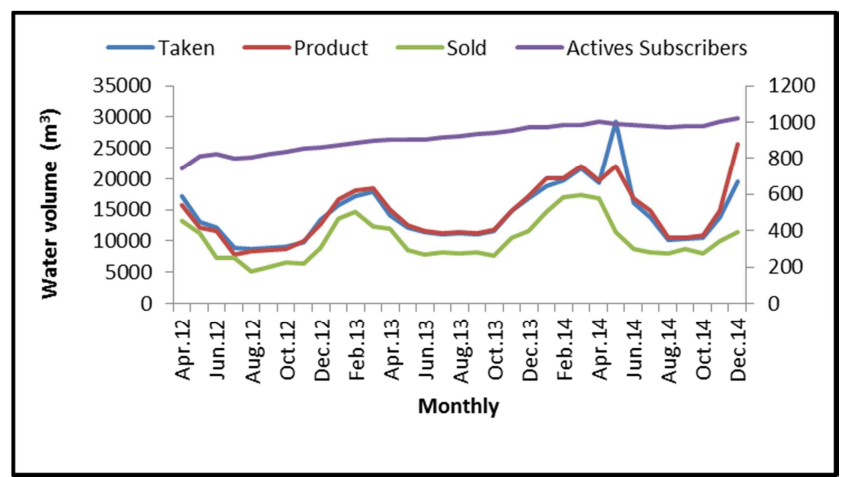

Figure 5. Monthly change in volumes of water withdrawn, produced, sold and the number of Savè subscribers from 2012 to 2014.

Table 5. Types of livestock and associated tropical livestock units (TLU).

\begin{tabular}{|c|c|c|c|c|c|}
\hline \multicolumn{6}{|c|}{$(2012-2013)(2013-2014)$} \\
\hline Types & UBT & Number of animals & Total TLU & Number of animals & Total TLU \\
\hline Cattle & 0,7 & 200 & 140 & 300 & 210 \\
\hline Sheep & 1,15 & 50 & 58 & 75 & 86 \\
\hline Goats & 0,2 & 20 & 4 & 25 & 5 \\
\hline Total & & & 202 & & 301 \\
\hline
\end{tabular}

\subsubsection{Volumes of Water Withdrawn by Livestock}

The livestock population at the Ilauko site projected on the basis of current trends is presented in Table 5 . The number of livestock projected in 2014 is estimated at 300 TLU, of which $100 \%$ is assumed to be drunk at the site of Ilauko in the dry season. The daily consumption of livestock corresponds to $12 \mathrm{~m}^{3} /$ day /unit. Transhumance occurs frequently on the site during the dry season for at least (06) months (November to April), i.e. 180 days. The total volume of pastoral consumption is thus estimated at $2160 \mathrm{~m}^{3}$. This volume is negligible compared to the volumes consumed for drinking water supply and for agriculture. This difference may be due to the lack of knowledge of the total number of transhumant herds that exploit the Ouémé River, as their second watering point during the dry season and also by the limited number of herds on the site.

\subsection{Analysis of Water Balance Components}

Table 6 shows the water balance of the Ilauko reservoir based on 02 pumps use during April-March months of 20122013 and 2013-2014 years. During the two periods, annual variations in reservoir volume are all positive, respectively $2,179,215 \mathrm{~m}^{3}$ and $598,452 \mathrm{~m}^{3}$. These annual variations obtained in the second period show the anthropic pressure in
Ilauko reservoir. Thus, the holding shows that the inflows are higher than the outflow volumes. Precipitations falling directly into the reservoir are in low proportions compared to runoff in 2012-2013 and 2013-2014. During these periods, the volumes of water precipitated represent respectively $60 \%$ and $45.96 \%$ of the contributions of runoff, while they represent $73.34 \%$ and $49.62 \%$ of the volumes evaporated. This supposes that the most part of the water precipitated in the Ilauko reservoir is at the same time evaporated under the effect of heat, which can be attributed may be to the impact of climate changes. The average losses by evaporation in the reservoir in 2012-2013 and 2013-2014 are evaluated respectively to $4,905,102 \mathrm{~m}^{3}$ and $5,531,866 \mathrm{~m}^{3}$ and represent about of $66.36 \%$ and $68 \%$ of the total volume out of the reservoir. It follows from the above results that evaporation the predominant factor in the decreasing on water quantity in the reservoir. The findings of the works of Liebe (2002) confirmed these results. During the campaign (2012-2013) and (2013-2014), more than $33.15 \%$ and $31.48 \%$ of water are taken from this reservoir to satisfy the different usages. Nevertheless, water volumes used in agriculture represent respectively $23 \%$ and $22 \%$ of outgoing volumes during the period (2012-2013) and (2013-2014). The other samples are of a crippled quantity, which is negligible (infiltration). Finally, the errors related to the components, infiltrations, 
contributions in terms of pumping and evaporations are respectively estimated at $\pm 0.3 \% ; \pm 10 \%$ and $\pm 5 \%$ during these two periods considered.

Figure $6 \mathrm{a}$ and $6 \mathrm{~b}$; present the monthly water balance in the Ilauko dam for the seasons, 2012-2013; 2013-2014. Analysis of these figures reveals that, for the full seasons 2012-2013 and 2013-2014, the water supplies in the reservoir are weak. The starting of the rainy season produces low runoff from the Ouémé River to the dam.

Table 6. Summary of the different component of the hydrological balance on the Ilauko reservoir over the period April March (2012-2013), April 2013-March 2014 (full seasons).

\begin{tabular}{lll}
\hline Water Balance component $\left.\mathbf{( m}^{\mathbf{3}}\right)$ & April-March (2012-2013) & April-March (2013-2014) \\
\hline Direct rainfall & $3,597,825 \pm 359783$ & $2,744,760 \pm 274,476$ \\
Surface runoff & $5,971,968 \pm 597,196.8$ & $5,971,968 \pm 597,196.8$ \\
Annual total inflow & $9,569,793 \pm 697,199.7$ & $8,716,728 \pm 657,252.68$ \\
Evaporation losses & $4,905,102 \pm 735,765$ & $5,531,866 \pm 877,014$ \\
Infiltration losses & $35,778 \pm 107,98$ & $30,000 \pm 128,64$ \\
Samples for various uses & $2,449,698 \pm 122,485$ & $2,556,410 \pm 127,821$ \\
Annual total outflow & $7,390,578 \pm 745,968$ & $8,118,276 \pm 886,279,74$ \\
Initial reservoir storage & $3,102,000$ & $5,281,215$ \\
Final reservoir Storage & $5,281,215$ & $5,879,667$ \\
Annual change in réservoir volume & $2,179,215$ & 598,452 \\
\hline
\end{tabular}

Concerning the water losses in the reservoir, analysis of the water balance shows that the natural factors (evaporation) combined to the water withdrawn characterized this situation.
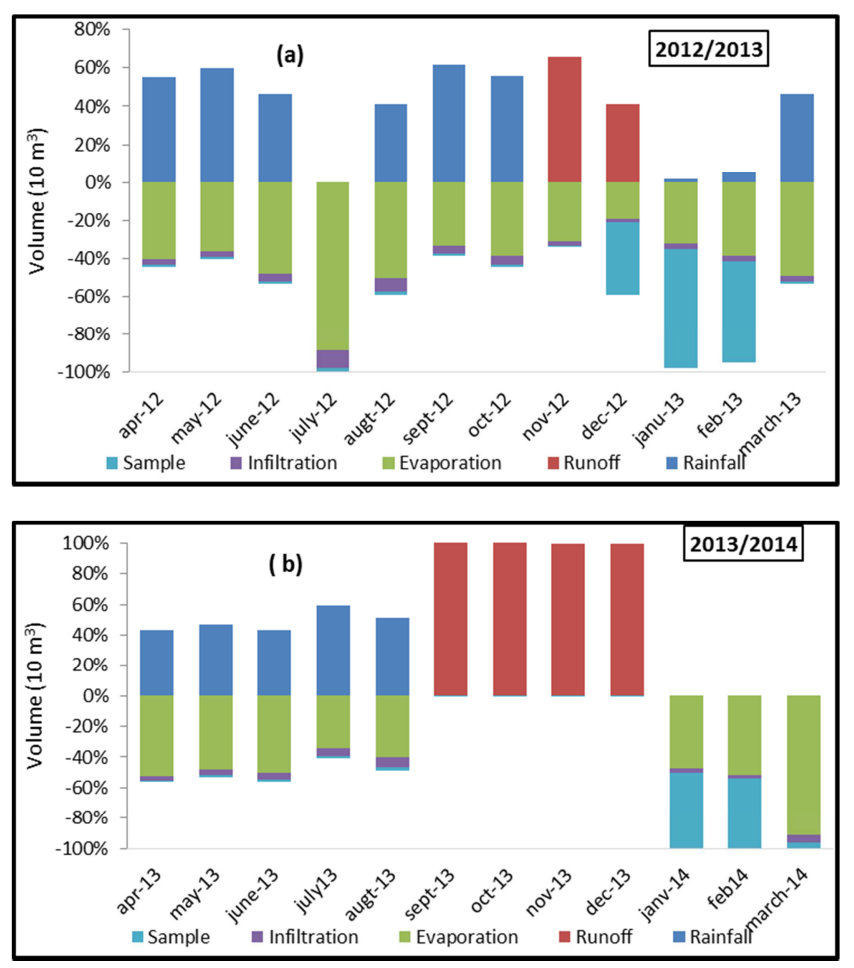

Figure 6. Monthly water balance in the Ilauko dam (April 2012-March 2013, April, 2013-March 2014).

\section{Conclusion}

The aim of this study was to assess the water balance in the Ilauko dam. The installation of hydro-rainfall stations by the two large structures (SUCOBE SA and SONEB) allows to collect the data need for the analysis. In the reservoir of Ilauko, three main actors intervened in the use of water: the Sugar Company of Savè, for the production of sugarcane;
SONEB, for the supply of drinking water and livestock watering. Knowledge of these actors allows an assessment of the reservoir's hydrological balance. Finally, the overall assessment of water balance over the period of hydrological monitoring indicated that Ilauko reservoir mobilization ranges from 13 to 15 million $\mathrm{m}^{3}$ between the periods 2012 2013 and 2013-2014. This study revealed also that the inflows in the reservoir are greater than the outflows. Thus, the annual variations in the volume of the reservoir obtained in 2012 and 2013 are positive and were $2.179 .215 \mathrm{~m}^{3}$ and $598.452 \mathrm{~m}^{3}$. Therefore, there are less of anthropic activities that are exerted on the reservoir during these periods. In the same way, it was noted that on the Ilauko dam $68 \%$ of the water volumes are evaporated, $0.5 \%$ infiltrate and $32 \%$ are withdrawn to face the irrigation needs and drinking water supply of Savè town and its surroundings.

\section{References}

[1] Baba - Moussa A. (2012). Expérience liée à l'exploitation du barrage de la Société sucrière de Savè pour l'alimentation en eau potable de la ville de Savè au Bénin. Rencontre du dialogue africain sur la sécurité alimentaire énergétique et hydrique. Nairobi., 29 Déc. pp 1-11.

[2] Lebel T. and Viscbel T., (2005). (Lebel T. and Viscbel T. (2005). Climat et cycle de l'eau en zone tropicale: un problème d'échelle; C. R. Géoscience., 337 pp. 29-38.

[3] Zannou, A., Lawin, E., Sintondji, L., Gohoungossou, A. et Vodounou, J. B. (2011). Contribution du projet Ouémé-2025 à l'étude de la dynamique et de la disponibilité des ressources en eau du bassin de l'Ouémé. Article. (ripiecsa).

[4] Awo-Affouda, U. (2009). Projet d'AEP des villes de Savè Dassa-Glazoué et Savalou à partir d'eaux de surface. Mémoire pour l'obtention d'un Master en eau et environnement, 97p.

[5] Celeste A. B. \&Billib M. (2010). The Role of Spill and Evaporation in Reservoir Optimization Models. Water Resources Management, 24, (4), 617-628. 
[6] Martínez-Granados, D., Maestre-Valero, J. F., Calatrava, J. y Martínez-Álvarez, V. (2011). "The economic impact of water evaporation losses from water reservoirs in the Segura basin, SE Spain". Water Resources Management, 25 (13): 3153-3175.

[7] Garg, K. K., Karlberg, L., Barron, J., Wani, S. P., Rockstrom, J.1, (2012). Assessing impacts of agricultural water interventions in the Kothapally watershed, Southern India. Hydrol. Process. 26, 387-404.

[8] Dubreuil P., CHAPERON P., GUISCAFRE J. et HERBAUD J., (1972). Recueil des données de base des bassins représentatifs et expérimentaux. Années $195 \quad 1-1969$. ORSTOM, Paris, 916 p.

[9] Vuillaume G, (1981). Bilan hydrologique mensuel et modélisation sommaire du régime hydrologique du lac Tchad. CAHIERS ORSTOM. SERIE HYDROLOGIQUE, 1981, vol. 18, no 1, p. p. 23-72.

[10] Allen R. G., Pereira L. S., Raes D., \& Smith M. (1996). Crop evapotranspiration - guidelines for computing crop water requirements- FAO Irrigation and drainage paper No. 56. $F A O$, Rome, Italy, 326p.

[11] Abdellaoui B., Merzouk A., Aberkan M., \& Albergel J. (2002). Bilan hydrologique et envasement du barrage Saboun (Maroc). Revue des Sciences de l'Eau, 15, (4), 737-748.

[12] Fowé T., (2015). Simulation et optimisation du fonctionnement du barrage de Boura en zone soudanienne du Burkina Faso. " Thèse de doctorat en sciences et technologies de l'eau, de l'énergie et de l'environnement, à l'institut international d'ingénierie de l'eau et de l'environnement ». $261 \mathrm{p}$.

[13] Institut géographique national, (1992). Une équipe de professionnels au service du développement du Bénin.

[14] Lebdi, \& Mathlouthi (2002). Evaluation de la fiabilité de gestion d'un barrage réservoir pour des événements secs. Hydrological Sciences Journal, 53. 6, 1194-1207, DOI: 19.1623/hysj.53.6.1194.

[15] Liebe, J., (2002). Estimation of Water Storage Capacity and Evaporation Losses of Small Reservoirs in the Upper East Region of Ghana. Germany, University of Bonn (Diploma Thesis).

[16] Cecchi P., Meunier-NikiemaA., Moiroux N., \& Sanou B. (2009). Towards an Atlas of Lakes andReservoirs in Burkina Faso. Small Reservoirs toolkit, 23p.

[17] Rosenberry D. O., Winter T. C., \& Likens G. E. (2007). Comparison of 15 evaporation methods applied to a small mountain lake in the northeastern USA. Journal of Hydrology, 340, 149-166.

[18] Tanny J., Cohen S., Assouline S., Lange F., Grava A., Berger D., Teltch B., \&Parlange M. B. (2008). Evaporation from a small water reservoir: Direct measurements and estimates. Journal of Hydrology, 351, 218-229.

[19] Piper B. S., Plinston D. T., \& Sutcliffe J. V (1986). The water balance of Lake Victoria. Hydrological Sciences Journal, 31, (1), 25-37.

[20] Güntner A., Krol M. S., Araújo J. C. D. E., \& Bronstert A. (2004). Simple water balance modelling of surface reservoir systems in a large data-scarce semiarid region. Hydrological
Sciences Journal, 49, (5), 901-918.

[21] Sukhija B. S., Reddy D. V., Nandakumar M. V., \& Rama (1997). A method for evaluation of artificial recharge through percolation tanks using environmental chloride. Ground Water, 35, (1), 161-165.

[22] Mugabe F. T., Hodnett M. G., \& Senzanjea (2003). Opportunities for increasing productive water use from dam water: a case study from semi-arid Zimbabwe. Agricultural Water Management, 62, (2), 149-163.

[23] Kingumbi A., Besbes M., Bourges J., \& Garetta P. (2004). Evaluation des transferts entre barrage et aquifères par la méthode de bilan d'une retenue en zone semi-aride. Cas d'El Haouareb en Tunisie centrale. Revue des Sciences de l'Eau, 17, (2), 213-225.

[24] Lacombe G. (2007). Evolution et usages de la ressource en eau dans un bassin versant amenage semi aride. Thèse de doctorat, Université Montpellier 2, Fance, 306p.

[25] SDAGE, (2013). (Schéma Directeur d'Aménagement et de Gestion des Eaux du bassin de l'Ouémé). Rapport SDAGE Version finale-Volume-Volume $1 \& 2$. Direction Générale de l'Eau.

[26] Winter T. C. (1981). Uncertainties in estimating the water balance of lakes. Water Resources Bulletin, 17, (1), 82-115.

[27] Sacks, L. A., Swancar, A., Lee, T. M. (1998). Estimating groundwater exchange with lakes using water-budget and chemical mass-balance approaches for ten lakes in ridge areas of polk and Highlands Counties, Florida. In: U. S. Geological Survey Water-Resour. Inv. Rep., pp. 4133.

[28] Dingman S. L. (1994). Physical Hydrology. Macmillan, New York, USA.

[29] Tim D. (2008). Fundamentals of Hydrology. Routledge Taylor \& Francis Group, London and New York.

[30] Vallet-coulomb C., Legesse D., Gasse F., Travi Y., \& Chernet T. (2001). Lake Evaporation estimates in tropical Africa (Lake Ziway, Ethiopia). Journal of Hydrology, 245, 1-18.

[31] Lowe L. D., Webb J. A., Nathan R. J., Etchells T., \&Malano H. M. (2009). Evaporation from water supply reservoirs: An assessment of uncertainty. Journal of Hydrology, 376, 261274.

[32] Winter T. C., Rosenberry D. O., \& Sturrock A. M. (1995). Evaluation of 11 equations for determining evaporation for a small lake in the north Central United States. Water Resources Research, 31, 983-993.

[33] LaBaugh J. W. (1985). Uncertainty in phosphorus retention, Williams Fork Reservoir, Colorado. Water Resources Research, 21, (11), 1684-1692.

[34] Lee T. M. \& Swancar Amy (1997). Influence of Evaporation, Ground Water, and Uncertainty in the Hydrologic Budget of Lake Lucerne, a Seepage Lake in Polk County, Florida. US Geological Survey water-supply paper (USA), 61p.

[35] Zandagba J. (2012). Impact des changements climatiques sur les ressources en eau du bassin de l'oueme à savè. " Mémoire de Master of Science en HGIRE à la CIPMA-Chaire UNESCO /FAST/UAC. 43p. ». 